Available online at: http://journal.uinsgd.ac.id/index.php/kt

KhazanahTheologia, Vol. 2 No. 2: 81-93

DOI: $10.15575 /$ kt.v2i2.8984

\title{
Hermeneutik Pedagogis Maria Magdalena
}

\author{
John C. Simon ${ }^{1 *}$, M. Ramli ${ }^{2}$ \\ ${ }^{1}$ Program Studi Ilmu Teologi STT Intim Makassar, Indonesia \\ ${ }^{2}$ Departemen Studi Pendidikan Kristiani STT Intim Makassar, Indonesia \\ Email: tajaksebakal@gmail.com
}

\begin{abstract}
Early Christian tradition placed Mary Magdalene as a sacred woman, who because of her divine God made her worthy of being a witness to the resurrection. Mary became an epitome for many who were awake in faith searching for Him on Easter morning. He is also a model of the church in its pilgrimage seeking God. Using a hermeneutics perspective, dealing with the Bible, Paul Ricoeur clearly distinguishes between reading and interpreting activities, "exegesis" and "hermeneutics". "Interpretation" not only means "exegesis", but "exegesis" as well as "hermeneutics". Productive hermeneutics bear a thesis, that is, the position of faith which contains free ethical choices. It is in this light that Mary Magdalene and her life will be seen in a hermeneutical perspective in order to arrive at an emancipatory ethical calling. In a pedagogical perspective, Maria's life values are: sensitivity-compassion, missionary vocation to be an agent of change, and wise creativity.
\end{abstract}

Keywords: Mary Magdalene; pedagogical; hermeneutic; productive; missional; compassionate.

\begin{abstract}
Abstrak
Tradisi kristiani awal menempatkan Maria Magdalena sebagai perempuan suci, yang karena kesuciaannya Allah melayakkannya menjadi saksi kebangkitan. Dengan menggunakan perspektif hermeneutik, berhadapan dengan Alkitab, metode Paul Ricoeur secara jelas membedakan antara aktivitas membaca (reading) dan menafsir (interpreting), "eksegese" dan "hermeneutik". Jika "menafsir" berorientasi ke masa lalu (eksegese), maka "membaca" menghasilkan orientasi ke masa kini (hermeneutik). Jadi, "tafsir" bukan hanya berarti "eksegese", tetapi "eksegese" sekaligus "hermeneutik". Dengan hermeneutik produktif diusung sebuah tesis, yaitu posisi iman yang mengandung pilihan etis yang membebaskan. Dalam terang seperti itulah Maria Magdalena dan hidupnya hendak dilihat dalam perspektif hermeneutis untuk menibakan pada panggilan etis emansipatoris. Dalam perjumpaannya dengan Yesus yang bangkit, Maria Magdalena diperkenalkan sebagai perempuan dengan nilai-nilai pedagogis yang luhur. Dalam perspektif pedagogis, nilai-nilai hidup Maria adalah: kepekaan hati-belarasa, panggilan misional-agen perubahan, dan kreativitas yang bijaksana.
\end{abstract}

Kata Kunci: Maria Magdalena; pedagogis; hermeneutic; produktif; missional; belarasa.

\section{PENDAHULUAN}

Tulisan ini bermaksud menelaah hidup seorang tokoh perempuan di dalam Alkitab, yaitu Maria Magdalena. Baik Maria Magdalena maupun Maria ibu Yesus, keduanya menjadi ibu bagi semua orang Kristen pada era patristik awal. Keibuan mereka lalu ditransfer kepada gereja (Hovorun, 2015; Krueger, 2019). Gambaran gereja sebagai ibu diterima luas dalam oecumene Kristen, khususnya di Afrika Utara. Di Aleksandria, khususnya, Klemen memperkenalkan gereja sebagai ibu dengan mengambil referensi pada kata-kata Yesaya: "Sebab beginilah firman Tuhan: Sesungguhnya, Aku mengalirkan kepadanya keselamatan seperti sungai, dan kekayaan bangsa-bangsa seperti batang air yang membanjir; kamu akan menyusu, akan digendong, akan dibelai-belai di pangkuan. Seperti seseorang yang dihibur ibunya, 
demikianlah Aku ini akan menghibur kamu; kamu akan dihibur di Yerusalem" (Yesaya 66:12-13) (Hovorun, 2015). Seorang ibu akan membawa anaknya dekat dengannya. Kita pun menyebut ibu kita dengan gereja.

Gambaran ibu menjadi populer dalam dunia Kristen sebagai reaksi atas perpecahannya: ibu yang menyatukan anak-anaknya. Siapa yang menolak gereja akan membahayakan keselamatannya, sebagaimana diungkapan oleh Cyprianus dari Kartago dengan kata-katanya yang terkenal: "Ia yang tidak mengaku Allah sebagai Bapa, ia juga tidak mengakui gereja sebagai ibunya" (Hovorun, 2015). Gambaran perempuan ini menjadi sangat kuat dalam mengamankan kesatuan gereja. Pada saat yang sama, gambaran ini berkontribusi untuk mempersepsikan gereja sebagai bernilai dalam dirinya, jika tidak terpisah dari Kristus.

Maria Magdalena tentu bukan sosok perempuan biasa (Chung Yen, 2005). Ada 12 ayat dalam keempat Injil kanonik, yang berasal dari tahun 70-100 M, yang berisi rujukan pada Maria Magdalena atau Maria dari Magdala. Ayat-ayat berikut menyebutkan panggilan nama tersebut: Matius 27:56; 27:61; 28:1; Markus 15:40; 15:47; 16:1; 16:9; Lukas 8:1; 24:10; Yohanes 19:25; 20:1; 20:18. Tradisi kristiani awal menempatkan Maria Magdalena sebagai perempuan suci, yang karena kesuciaannya Allah melayakkannya menjadi saksi kebangkitan.

Penghormatan pertama atas Maria Magdalena muncul di Gereja-gereja Timur. Tahun 889 M, kaisar Bizantium, Leo VI membangun rilikui (devosi/penghormatan) untuk Maria Magdalena di Gereja EnTopois, di Konstantinopel. Di Gereja-gereja Barat, devosi/penghormatan atas Maria Magdalena sangat awal terjadi dan betul-betul berkembang setelah Paus Gregorius (590-604 M) dalam dua kesempatan berbeda mendukung dan meresmikan devosi populer terhadapnya. Untuk meyakinkan Gereja Katolik, ia berkata: "Ketika saya memikirkan pertobatan Maria, rasanya saya ingin menangis. Ia betul-betul memperhitungkan apa yang telah ia buat dan apa yang akan dia lakukan. Dengan mencintai kebenaran, dia menghapus dosa-dosanya dengan air matanya sendiri" (Tardelly, 2011). Puncaknya pada 20 April 1050, Paus Leo IX mengeluarkan sebuah bulla (keputusan suci dari Paus) yang menetapkan Maria seorang santa dan dikukuhkan ulang oleh Paus Stefanus IX pada 6 Maret 1058. Begitulah tradisi Katolik memandang Maria Magdalena sebagai perempuan kudus (santa, orang kudus) yang paling banyak diumpat karena kontroversinya, namun diberkati dan layak menjadi salah satu pengantara umat dan atau gereja untuk datang kepada Allah (Callahan, 2006; Tripp, 2019, pp. 253-276). Namun, ia jelas adalah seorang penginjil perempuan mula-mula yang turut menjadi saksi dari peristiwa kebangkitan Yesus. Karena ia adalah saksi dari kebangkitan, maka ia dapat disejajarkan dengan rasul-rasul lainnya, sebagai seorang rasul perempuan (Callahan, 2006). Maria menjadi contoh bagi banyak orang yang terjaga dalam iman mencari Dia di pagi hari Paskah. Dia juga model dari gereja dalam peziarahan mencari Tuhan.

Beberapa studi terdahulu tentang Maria Magdalena dilakukan oleh beberapa ahli. Lie Chung Yen mendalami sosok Maria Magdalena dengan perspektif historis. Ia mendalami konteks pemberontakan yang silih berganti terjadi. Magdala, tempat di mana Maria hidup, lalu dikenal sebagai "tanah yang diliputi bayangan kematian". Yen juga memperkenalkan Maria sebagai sosok pelacur yang bertobat. Konteks ini membuat Maria menjadi sosok yang terbiasa dengan dunia yang keras, yang menempanya menjadi pribadi yang tangguh dan militan ketika menjadi para pengikut Yesus (Chung Yen, 2005). Tokoh lain Sidney Callahan dengan perspektif historis menggali konteks Palestina dengan sistem sosial dan ekonominya yang menindas. Masyarakat Yudea di mana Maria hidup adalah yang bertatanan sangat tidak adil. Kekerasan dan penindasan sangat biasa terjadi di sini, lebih lagi itu tertuju pada kaum perempuan yang sering mengalami marginalisasi. Inilah konteks di mana Maria tumbuh sebagai perempuan yang terbiasa hidup menderita dan mengikuti gerakan Yesus dengan satu visi untuk ikut mentransformasi 
masyarakat menjadi adil dan sejahtera (Callahan, 2006). Sementara itu Reynaldo Fulgentio Tardelly, dengan menggunakan analisis semiotik (kebahasaan), menjelaskan kata Magdala sebagai sebuah jalur perdagangan yang ramai dan tempat orang berjualan ikan. Tujuan analisis semiotik ini adalah untuk memperlihatkan latar belakang kehidupan Maria sebagai seorang nelayan --seperti umumnya para murid Yesus-- yang sehari-harinya bergelut dengan kehidupan yang keras sehingga ia menjadi pribadi dewasa dan matang oleh pengalaman (Tardelly, 2011). Tokoh lain Sr. M. Henrika dengan menggunakan perspektif misiologis mengatakan bahwa perjumpaan dengan Yesus telah mengubah hidup Maria. Rasa sedih karena penindasan menjadi sukacita yang mendalam, dan keputusasaan karena menjadi sasaran ketidakadilan diubah menjadi pengharapan. Lebih dari itu, Yesus memanggil, memberi kepercayaan dan penugasan kepada Maria untuk menghadirkan damai sejahtera (Henrika, FSGM, 2011). Terakhir Bronwen Wilson, dengan perspektif teologis menjelaskan konteks yang keras dan cenderung seksis terhadap para perempuan menempatkan Maria Magdalena tumbuh menjadi seorang pembimbing yang sangat baik untuk orang kristiani dewasa ini yang berusaha menjadi orang yang sungguh mengasihi Allah dan sesama. Maria mewakili perempuan misionaris yang bersemangat besar untuk mencari dan menemukan kebenaran. Inilah yang dalam dunia teologi dikenal sebagai "fides quarens intellectum", yaitu iman yang mencari terus-menerus pengetahuan akan kebenaran Allah dan diwujudkan dengan upaya keras tanpa lelah hingga sampai mendapatkannya (Wilson, 2019). Yang berbeda dalam penelitian ini adalah bahwa penulis menggunakan perspektif hermeneutik pedagogis, untuk menggali nilai-nilai pedagogis dari pengalaman hidup Maria Magdalena bagi hidup manusia di hari ini. Perspektif ini sekaligus kebaruan yang membedakan antara tulisan ini dengan tulisan-tulisan terdahulu.

Melalui penelusuran ini akan dicari apa yang menjadi nilai-nilai pedagogis yang diperjuangkan oleh seorang Maria Magdalena. Tesis tulisan ini adalah bahwa nilai-nilai hidup yang dijalani Maria Magdalena itu sangat penting untuk hidup pribadi dan komunitas di hari ini di tengah perjuangan hidup beriman yang tidak mudah. Melalui penelusuran hermeneutis, didapati bahwa semua nilai itu penting untuk menginspirasi sebuah tindakan iman konkret di dalam konteks yang dihidupi.

\section{METODE PENELITIAN}

Metode penelitian yang digunakan dalam tulisan ini adalah hermeneutik, secara khusus titik beratnya pada hermeneutik Paul Ricoeur. Hermeneutik sebagai penafsiran atas teks kitab suci sangat dekat dengan persoalan seseorang menerapkan hasil-hasil penafsiran teks agamanya dalam ruang-ruang publik (Ariarajah, 2005; Frederiks, 2005; Moyaert, 2017). Dapat dikatakan bahwa penafsiran atas teksteks keagamaan bukanlah aktivitas sepi dari hubungan dengan orang-orang lain dan bagaimana orang lain digambarkan berdasar pada hasil penafsiran itu. Hermeneutik berasal dari kata Yunani hermeneuein, yang berarti "menafsirkan" (to interpret). Dari sini muncul perluasan makna kata menjadi "mengungkapkan" (to express), "menjelaskan" (to explain), "menerjemahkan" (to translate) (Palmer, 1980). Kata ini juga didefinisikan secara beragam dan bertingkat.

Ragam dan tingkat pertama adalah hermeneutik reproduktif (Mantzavinos, 2020) (Warnke, 2020). Friedrich Schleiermacher dianggap menjadi tokoh kunci hermeneutik reproduktif yang ingin kembali ke masa lalu dengan proyek rekonstruksi dan reproduksi. Tugas hermeneutik adalah menghubungkan seseorang dengan "ekspresi genius" atau "pengarang serba tahu" (omniscient author) -bahkan "pengarang dianggap tidak dapat salah" - dan menjadikannya itu sezaman dengan orang tersebut (pembaca). Jarak antara pengarang dan pembaca cenderung dianggap negatif, dan harus diatasi. Upaya mengatasi jarak menyebabkan alih-alih makna menjadi jelas, yang ada adalah pengulangan (copy-paste, reproduktif) masa lalu untuk dihadirkan di hari ini. William Dilthey (1833-1911) meneruskan proyek 
hermeneutik reproduksi. Menurut Dilthey "the ultimate aim of hermeneutics is to understand the author better than he understands himself" (tujuan akhir hermeneutik adalah memahami pengarang lebih baik daripada pemahamannya tentang dirinya sendiri) (Ricoeur, 1982). Lewat pernyataan di atas, tergambar bahwa hermeneutik memang didedikasikan memahami yang lain (dhi. teks atau pengarang), tetapi saat bersamaan melupakan diri sendiri. Hermeneutik reproduktiflalu jatuh pada arogansi makna tunggal.

Ragam dan tingkat kedua adalah hermeneutik produktif (Mantzavinos, 2020) (Warnke, 2020). Tokoh kunci hermeneutik produktif adalah Hans-Georg Gadamer. Ia mengatakan: "[...] the meaning of a text goes beyond it's author [...] That is why understanding is not merely a reproductive, but always a productive attitude as well" (arti dari sebuah teks melampaui pengarangnya [...] Itulah mengapa pemahaman bukan hanya reproduksi, tetapi selalu merupakan sikap produktif juga" (Gadamer, 1975). Hermeneutik produktif ini mendobrak penunggalan makna dan membuka perspektif "keragaman makna" (surplus of meaning). Hermeneutik ini mencapai puncaknya pada pemikiran filsafat hermeneutik Paul Ricoeur. Dasarnya adalah apa yang Ricoeur katakan "meaning of a text lies not behind the text but in front of it" (Makna teks sendiri tidak terletak di belakang teks melainkan di depannya) (Ricoeur, 1982). Karena makna ada di depan teks, makna melampaui intensi pengarang, yang berarti membuka kemungkinan bagi polisemi makna.

Hermeneutik produktif mengusung sebuah tesis, yaitu posisi iman yang memuat panggilan etis yang membebaskan (Ricoeur, 1980). Teks yang bersifat produktif dapat membuka diri (penafsir/pembaca) di hadapan teks yang mendorong kehendak untuk bertindak. Tindakan yang dimaksud adalah tindakan etis emansipatoris. Inilah prinsip etika emansipasi Ricoeur yang dihasilkan melalui proses penafsiran teks, yang dasarnya adalah "cinta dan keadilan" (love and justice) (Simon, 2019) (Ricoeur, 1995). Di sinilah hidup sehari-hari ditransfigurasi oleh perjumpaan dengan teks dan mengantar pada tindakan etis tentang cinta dan keadilan. Dalam terang seperti itulah Maria Magdalena dan hidupnya hendak dilihat dalam perspektif hermeneutik produktif untuk menibakan pada panggilan etis emansipatoris.

Dalam kajian hermeneutik produktif, berhadapan dengan Alkitab, Ricoeur secara jelas membedakan antara aktivitas "membaca" (reading) dan "menafsir" (interpreting), "eksegese" (=menempatkan teks dalam konteks masa lalu) dan "hermeneutik" (=menempatkan teks dalam konteks masa kini)" (Ricoeur, 1982). "Membaca" menekankan pada pembaca teks yang mempunyai perspektif atau pendekatan tertentu terhadap teks. "Menafsir" menekankan pada kemampuan menggali teks dan makna yang terdapat di dalam atau di belakang teks. Jika yang terakhir, "menafsir", dikembangkan oleh metode tafsir historis-kritis yang berorientasi ke masa lalu (eksegese), maka "membaca" menghasilkan pendekatan yang sekarang disebut reader's response yang orientasinya ke masa kini (hermeneutik). Jadi, "tafsir" bukan hanya berarti "eksegese", tetapi "eksegese" sekaligus "hermeneutik".

Secara teknis, urutan penafsiran yang Ricoeur lakukan adalah pertama-tama prefiguration, kemudian configuration dan akhirnya refiguration. Dalam langkah pertama, prefiguration, kita berpikir naif atau pra-kritis. Tahap ini sering juga disebut membaca dari dekat (close reading), memahami teks dan menggali makna secara intuitif dalam rangka sebuah keyakinan. Dalam langkah kedua, configuration, kita memasuki pemikiran kritis. Pada tahap ini seorang penafsir mulai mendiskusikan hasil bacaannya atas teks dengan bahan-bahan tafsir dari para ahli yang mengusung tujuan ganda, yaitu kritis pada teks dan kritis pada sejarah penafsiran teks. Sedangkan dalam langkah ketiga, refiguration, kita memasuki pemikiran pasca-kritis. Pada tahap ini hasil penafsiran pada tahap sebelumnya dipakai untuk mengonstruksi pesan-pesan moral-etis-emansipatoris bagi hidup di masa kini (Stiver, 2001) (Colby \& H. Bodily, 2018). 
Dalam ketiga tahap ini tekanan diletakkan pada si pembaca. Pembaca dan pengalamannya merayakan kekayaan makna (surplus of meaning). Memberi tempat kepada pembaca untuk menentukan makna sebuah teks akan melahirkan suatu eisegese, yaitu penyelundupan pikiran pembaca ke dalam teks (Setio, 2010) (Setio, 2006). Secara metodik, perkembangan hermeneutik postmodern semakin mengaburkan perbedaan klasik antara eksegese (mengeluarkan makna) dan eisegese (memasukkan makna). Eisegese dapat ditoleransi jika penyelundupan pikiran bahkan kepentingan dari pembaca itu terjadi sejauh diletakkan dalam komunitas sehingga yang muncul adalah kepentingan komunitas (interpretive community). Terselip keyakinan bahwa di dalam komunitas inilah kepentingan yang lebih besar, yaitu kepentingan kerajaan Allah tentang keadilan (termasuk keadilan gender), perdamaian dan keutuhan ciptaan, tersimpan dan melampaui segala bentuk kepentingan pribadi (Gschwandtner, 2017). Pada dasarnya jenis penafsiran ini memahami bahwa pembaca perlu diberi ruang yang lebih leluasa untuk menentukan manfaat penafsiran yang diketemukan sedekat-dekatnya dengan konteks hidupnya dan menjawabnya.

\section{HASIL DAN PEMBAHASAN}

Urutan hasil dan pembahasan dengan memakai perspektif pedagogis Paul Ricoeur melalui metode penafsirannya adalah sebagai berikut. Pertama-tama akan dipaparkan kedudukan Maria Magdalena di dalam konteks yang dihidupinya. Bagian ini merupakan gabungan langkah pertama dan kedua dari metode tafsir Ricoeur, yaitu prefiguration dan configuration. Kemudian menjelaskan arti penting Maria Magdalena dalam gerakan Yesus. Bagian ini merupakan langkah kedua, yaitu configuration. Dan akhirnya menjelaskan Maria Magdalena dan nilai-nilai pedagogis yang diwariskannya. Bagian ini merupakan langkah ketiga, yaitu refiguration. Sebagai penutup akan dipaparkan beberapa kesimpulan.

\section{Maria Magdalena dan Konteks Hidupnya}

Inggrid Maisch, teolog perempuan Katolik asal Jerman, berpendapat bahwa nama Maria dari Magdala jauh lebih objektif ketimbang nama Maria Magdalena. Yang terakhir ini cukup sarat dengan bias jender, khususnya pandangan laki-laki atas perempuan tidak baik dan tidak bermoral. Padahal Maria dari Magdala jauh lebih dari itu, mempunyai karakter: berani, solider, penghibur orang berduka, tekun dan setia (Tardelly, 2011). Bahkan Sidney Callahan menjelaskan bahwa dari analisis bahasa dan budaya, nama Maria dari Magdala sangat jelas bahwa ia adalah seorang terpandang atau terkemuka di tengah masyarakat (Callahan, 2006). Bahkan besar kemungkinan bahwa Maria adalah pemimpin sebuah jemaat kristiani perdana.

Maria dari Magdala hidup dalam zaman yang bergolak di bawah pemerintahan bangsawan militer di Roma. Maria hidup di sebuah provinsi Roma di kawasan Laut Tengah yang banyak diterjang pemberontakan kaum petani dan perang saudara di antara raja-raja wilayah atau raja-raja boneka Roma. Pemberontakan orang Yahudi atas Raja Shalmanaser II asal Asyur (728 SM) dicatat dalam Hosea 10:13b14. Pemberontakan Makabe terjadi tahun 167-143 SM (lihat Makabe 9:2). Pemberontakan Yahudi terakhir terjadi tahun 66-70 M yang membuat kehancuran Yerusalem. Magdala sendiri hancur tahun 67 M. Panglima militer Roma, Vespasianus, dan anaknya, Titus, membantai habis penduduk Magdala. Pengalaman ini membuat Magdala dikenang sebagai "tanah yang diliputi bayangan kematian" (Chung Yen, 2005) Di zaman Maria hidup, Yudea diperintah oleh Herodes Agung (37-40 sM) yang terkenal bengis dan haus darah. Keadaan di Palestina pada abad pertama adalah contoh sistem sosial dan ekonomi yang bersifat menindas (Callahan, 2006). Keadaan-keadaan tersebut menunjukkan masyarakat yang 
bertatanan sangat tidak adil. Orang kaya menjadi semakin kaya dan orang miskin semakin tergilas dan melarat. Kekerasan yang tidak mengenal hukum dan penindasan yang kejam adalah hal biasa.

Dalam bahasa Ibrani "Mar" berarti gemuk, tebal, pahit, kuat dan suka berontak. "Mar" dalam bahasa Ibrani menjadi Miryam, bahasa Aram menjadi Maryam, bahasa Yunani menjadi Mariam, dan dalam bahasa Latin menjadi Maria (Chung Yen, 2005). Makna namanya itu yang kiranya tercermin dalam kenyataan bahwa Maria Magdalena atau disebut juga Maria dari Magdala hidup dalam zaman dan tempat yang rumit, yang telah memikat semua orang yang berusaha memahami Yesus dari Nazaret. Masyarakat kota yang berkembang pesat dan bersifat Yunani-Helenistik, yang terdiri dari orang Yunani, Romawi dan Yahudi, hidup di Palestina berdampingan dengan, atau menindas, masyarakat petani agraris Yahudi. Semua kelompok ini hidup di bawah kuk kekuasaan Romawi yang memerintah dengan tangan besi.

Jalan-jalan perdagangan membentang melalui Palestina dari peradaban-peradaban Timur menuju pelabuhan-pelabuhan laut di kawasan Laut Tengah. Agama yang berbeda-beda, baik dari Timur maupun Barat, memengaruhi kehidupan beragama orang Yahudi. Perpecahan internal yang bergolak menandai Yudaisme pada zaman itu. Ada sekte-sekte asketik, seperti kaum Esseni, yang memilih mengasingkan diri dari keramaian, di samping golongan keras, Zelotes, yang memberontak melawan Roma, namun akhirnya ditumpas dan musnah oleh militer Roma.

Dalam konteks yang keras itu, nasib Maria tidak jauh dengan rakyat kebanyakan. Ia hidup penuh dengan kepahitan. Hidup Maria sebanding dengan hidup mertua Ruth yang mengakibatkan ia dinamai Mara yang berarti kepahitan dan bukan Naomi yang artinya menyenangkan. "Mara" adalah bentuk lain dari "Mar", yang dalam bahasa Ibrani berarti "pahit", yang mencerminkan kepahitan hidup yang dialami oleh Maria (Chung Yen, 2005). Magdalena kerap dilukiskan dengan tengkorak, mungkin karena ia berdiri di bawah Salib di Bukit Tengkorak (Golgata), bisa juga karena ia dianggap akrab dengan kematian.

Magdala sebagai tempat asal Maria adalah sebuah kota besar di tepi danau Galilea atau karena luasnya disebut Laut Kinneret (Chung Yen, 2005). Magdala terletak di persilangan jalan utama perdagangan internasional Via Maris (Latin: Jalan Laut) antara Mesir dan Damaskus, Siria. Kota ini menyerupai kota singgah yang bersifat internasional karena menjadi pertemuan orang dari berbagai bangsa sambil membawa perilaku dan sistem kepercayaan mereka masing-masing. Secara moralitas sesungguhnya kota ini sangat rusak. Sihir dan perzinahan merajalela. Mungkin karena reputasi kota asal Maria ini, sehingga di kemudian hari Maria selama berabad-abad dikenal sebagai mantan pelacur (Chung Yen, 2005). Sekalipun muncul pula pandangan sebaliknya yang melihat Maria secara apresiatif dari Elisabeth S. Fiorenza, yang mengatakan, "the pre-Lukan tradition identifies Mary of Magdala as a woman 'from whom he has cast out seven demons' (cf. Mark 16:9 and Luke 8:2), then she is not thereby characterized as a 'sinner', but as someone who has experienced the unlimited (seven) liberating power of the basileia in her own life" [tradisi pra-Lukas mengidentifikasi Maria dari Magdala sebagai seorang perempuan 'dari siapa Dia telah mengusir tujuh setan' (band. Markus 16:9 dan Lukas 8:2), maka dia dengan demikian tidak dikategorikan sebagai 'orang berdosa,' tetapi sebagai seseorang yang telah mengalami kekuatan pembebas kuasa Allah yang tak terbatas dalam hidupnya sendiri] (Fiorenza, 1985). Basileia adalah kuasa Allah yang membebaskan. Visi basileia Yesus membuat orang seperti Maria pulih, sehat, tahir dan kuat kembali.

Dinamai Magdala (Ibrani "Migdal": menara) karena di sini berdiri menara pengawas milik militer Roma untuk mengamati seluruh rute utama perdagangan. Di sini juga para nelayan berlabuh dan menjual ikan mereka. Karena itu kota Magdala juga sering disebut "menara ikan" (Ibrani: Magdal Nunaiya) atau orang berbahasa Yunani menyebutnya "tempat ikan diasinkan" (Yunani: Tarichea) atau dikeringkan 
(Tardelly, 2011). Semua hasil olahan ikan itu dijual ke pasar-pasar di Yerusalem dan di ekspor hingga ke kota Roma.

Seperti jelas pada bagian sebelumnya, Ricoeur secara jelas membedakan antara aktivitas membaca (reading) dan menafsir (interpreting). "Menafsir" menekankan pada kemampuan menggali teks dan makna yang terdapat di dalam atau di belakang teks. "Membaca" menghasilkan pendekatan yang sekarang disebut reader's response yang basisnya adalah hermeneutik produktif, menambah dan menggandakan makna. Apa hasil hermeneutik terkait dengan hidup Maria? Hasilnya dapat dilihat dan ditemukan dalam makna bahwa konteks yang keras dan cenderung seksis para perempuan menempatkan Maria Magdalena menjadi pembimbing yang sangat baik untuk orang kristiani dewasa ini yang berusaha menjadi orang yang sungguh mengasihi Allah dan sesama. Maria mewakili perempuan misionaris yang bersemangat besar untuk mencari dan menemukan kebenaran (Wilson, 2019). Padanya iman yang diterminologikan sebagai "fides quarens intellectum", yaitu iman yang mencari terus-menerus pengetahuan akan kebenaran (Allah) diwujudkan dengan upaya keras tanpa lelah hingga sampai mendapat pembuktiannya. Sebelum dan sesudah kebangkitan, ia dapat berbalik menuju dunia baru dan melangkah untuk menempuh jalan kemuridan yang progresif dan revolusioner, yang maju dan mengubah keadaan.

\section{Tempat Maria Magdalena dalam Gerakan Yesus}

Dalam Lukas 8:1-3, Maria Magdalena memiliki tempat istimewa dalam gerakan Yesus. Ia diperkenalkan sebagai pribadi yang mengenal dan mengikuti Yesus bersama dengan kedua belas murid berjalan berkeliling dari kota ke kota dan dari desa ke desa memberitakan Injil Kerajaan Allah (Clifford, 2002). Maria menderita dengan tujuh setan yang selalu mengganggunya. Namun, menurut apa yang sering terjadi, penderitaan itu tidaklah seberapa jika dibandingkan dengan orang-orang yang kerasukan legion, yang berarti kurang lebih seribu setan sebagaimana yang terjadi pada orang di Gerasa. Yang jelas ia telah disembuhkan dari tujuh roh jahat atau roh jahat yang sempurna (angka 7) dalam kejahatannya, juga dari berbagai penyakit lainnya (Tardelly, 2011). Ia mengalami dan mengenali Yesus sebagai Ia yang dekat, yang menyembuhkan atau menyelamatkan. Yesus adalah orang yang selalu sama, penuh cinta, dekat dengan para murid-Nya, selalu mencari dan mencintai orang berdosa, mudah bergaul dengan siapa saja, tetapi pada saat yang sama setia pada panggilan-Nya, yang sering kali begitu sulit dipahami. Maria Magdalena juga bersama dengan perempuan-perempuan lainnya melayani rombongan Yesus dengan talenta, karunia dan berkat berupa kekayaan yang mereka miliki (ayat 2). Ia termasuk dari penginjil atau misionaris perempuan pertama yang diperkenalkan oleh Injil yang menjadi saksi yang setia dari kuasa kebangkitan Yesus (Ricci, 1994). Ketika hampir semua murid-Nya lari meninggalkan Yesus, Maria Magdalena bersama Yohanes dan Maria ibu Yesus, menyaksikan kematian-Nya di Kalvari (Matius 27:5556; Markus 15:40-41, Yohanes 19:25).

Dalam Yohanes 20:11-18, Maria Magdalena mengalami perasaan kehilangan Yesus. Kemudian menemukan kembali Yesus. Ia berjumpa dengan Yesus yang bangkit. Perjumpaan itu menjadi pola bagi perjalanan hidup, khususnya panggilan para perempuan, di mana Yesus mempercayai dan mengutus Maria, menunjuk pada bagaimana para perempuan pun diutus untuk ikut serta mengemban misi gereja dalam setiap tempat dan kesempatan (Johnson, 2003).

Narasi Yohanes 20:11-18 sangat menarik dicermati. Pagi-pagi menjelang fajar pada hari sesudah sabat, Maria Magdalena atau Maria dari Magdala, bergegas-gegas pergi menuju ke kuburan tempat Yesus dimakamkan. Dalam perjalanan itu, ia terus menangis. Ini merupakan ungkapan emosional dari pengalaman kehilangan karena kedekatan sebuah relasi antara Yesus dengan para murid tak terkecuali 
dengan Maria. Gelombang kepedihan dan kedukaan melingkupi hatinya. Lagi dan lagi gambaran tentang penangkapan, pengadilan dan penyaliban Yesus menyerbu hatinya.

Ketika memasuki kompleks pekuburan, Maria terkejut karena menemukan batu penutup pintu masuk makam telah terguling ke samping. Makam itu telah kosong. Dalam keadaan kuatir dan bingung, Maria berlari untuk memberi tahu para murid yang lain, katanya: "Tuhan, telah diambil orang dari kuburnya dan kami tidak tahu di mana Ia diletakkan" (Yohanes 20:2).

Petrus dan Yohanes berlari untuk melihat dan membuktikan sendiri makam yang kosong, kemudian pulang lagi. Akan tetapi Maria tetap tinggal di situ. Ia tidak mundur selangkah pun untuk memenuhi maksudnya. Ia bertekad bulat dan berdaya kuat untuk menemukan tubuh Guru yang amat dihormati dan dikasihinya. Dari hati yang paling dalam, Maria ingin memberikan upacara penghormatan atas tubuh Yesus, sesudah diperlakukan dengan amat kejam, diolok-olok, disesah dan amat menderita, dengan upacara pemakaman yang lazim untuk orang mati dalam tradisi Yahudi.

Ketika sedang menunggu di luar kubur, Maria terus menangis dan berdukacita. Terasa segala sesuatunya telah sirna. Musuh yang pendendam dan iri hati, pemimpin yang bejat, pengkhianatan sahabat-sahabat dekat (Petrus dan Yudas), semua itu telah membantu si penindas Roma menjatuhkan hukuman yang tidak adil bagi Yesus, yaitu hukuman mati di salib yang hina. Kematian seolah mengalahkan kehidupan. Hati Maria remuk redam karena keputusasaan dan tertindih ketidakberdayaan. Dalam harihari terakhir ini, ia, yang sebelumnya selalu mampu mengurus dan melayani orang-orang lain, menjadi kehilangan daya tanpa mampu berbuat apa-apa selain bersedih dan berdiri sebagai saksi di tempat eksekusi itu dan sekarang di kuburan ini.

Namun, ia mengalami suatu penglihatan. Dua orang malaikat berpakaian putih tampak dan bertanya kepadanya (Yohanes 20:12). Perhatian Maria sepenuhnya tertuju pada misinya sehingga ia tidak merasa panik. Maria dengan tenang menerangkan bahwa ia sedang mencari tubuh Yesus, dan ia meminta bantuan. Ketika sedang berbicara, ia tergerak untuk berputar ke arah sosok manusia yang ia lihat di dekatnya. Itu Yesus. Tetapi mula-mula Maria menganggapnya seorang tukang kebun. Yesus dengan sopan bertanya mengapa Maria menangis. Maria menjawab dan menerangkan usaha pencariannya. Kemudian Yesus berkata: "Maria". Maria mengenali sapaan itu. "Rabuni!" teriaknya dengan menggunakan sapaan penuh kerinduan, yang berarti "Guruku". Dalam jawaban-Nya, Yesus memberi tahu Maria untuk tidak menjamah atau memeluk-Nya, tetapi menyuruhnya pergi dengan segera dan memberi pesan kepada saudara-saudara yang lain bahwa "Aku akan pergi kepada Bapa-Ku dan Bapamu, kepada Allah-Ku dan Allahmu" (Yohanes 20:17).

Kisah larangan Kristus pada Maria untuk tidak menyentuh-Nya pasca kebangkitan (Yohanes 20:17) banyak menarik perhatian para Bapa Gereja (Tardelly, 2011). Hieronimus (abad ke-4) melihat ini sebagai transformasi iman dari seorang yang tidak percaya pada kebangkitan kepada orang yang percaya. Yohanes Kristostomus (abad ke-4) menjelaskan perkembangan itu demikian, dari "kepercayaan duniawi" (dalam adegan memeluk kaki Yesus) ke kepercayaan penuh akan keilahian Yesus (dalam adegan larangan menyentuh Yesus). Sementara itu, Gregorius Agung melihat adegan larangan menyentuh Yesus sebagai undangan untuk "menyentuh secara spiritual". Bapa Agustinus menjelaskannya sebagai metafor bangsabangsa kafir yang akhirnya percaya kepada Yesus.

Maria pergi. Ia memberitakan kepada para pengikut Yesus lainnya bahwa ia telah melihat Tuhan dan menyampaikan kepada mereka pesan yang harus disampaikannya. Apa yang dilakukan Maria ini dicatat dalam tradisi Gereja Barat dengan menyebut Maria Magdalena sebagai "Rasul kepada para rasul", "Rasul para Rasul atau "Rasul utama" (Apostola Apostolorum). Di Gereja Timur, ia disebut sebagai "Setara Rasul" (Isapostola) (Chung Yen, 2005). Kedua gelar kehormatan ini diberikan karena dalam tradisi 
dikisahkan bahwa Kristus yang bangkit menampakkan diri pertama kali kepada Maria Magdalena dan mengutus dia untuk mewartakan kabar gembira tentang kebangkitan tersebut.

Pengalaman Maria dari Magdala, yaitu persahabatannya yang memerdekakan dengan Tuhan, mengubah hidup dan pribadinya menjadi baru (Callahan, 2006). Dewasa ini, kita dapat membayangkan Maria sebagai orang yang menyambut baik tuntunan-tuntunan Roh dalam jemaat yang menghormati martabat perempuan, menghargai tubuh manusia, dan mendorong persamaan serta persahabatan antara laki-laki dan perempuan. Akhirnya, umat yang dimetaforakan sebagai kawanan yang berziarah dapat belajar dari Maria dari Magdala yang terus berharap akan bertemu dengan Guru yang telah mengubah hidupnya menjadi baru dan berarti. Itulah hakikat dari gereja yang hidup, yakni gereja yang terus mencari kebenaran Allah yang hidup.

\section{Maria Magdalena dan Nilai-nilai Pedagogis}

Bagian ketiga ini dapat disebut prefiguration, yakni proses menempatkan teks dalam konteks masa kini atau yang disebut hermeneutik. Proses menempatkan teks, yaitu Maria Magdalena, dalam konteks masa kini ini akan menghasilkan makna berupa nilai-nilai pedagogis melalui teladan hidup Maria Magdalena bagi hidup di masa kini.

Maria Magdalenan, melebihi perempuan lain mana pun yang diketahui, mengambil bagian sepenuhnya dalam pelayanan Yesus. Ia mengalami saat yang paling revolusioner dan memerdekakan dalam sejarah manusia. Ia adalah saksi pertama dari peristiwa kebangkitan dan saksi dari pengalaman tentang kekuatan cinta kasih di balik peristiwa kebangkitan itu. Tentang Maria Magdalena, Elisabeth S. Fiorenza menuliskan refleksinya bahwa: "Mary of Magdala was the most prominent of the Galilean disciples, because according to tradition she was the first one to receive a vision of the resurrected Lord" (Maria dari Magdala adalah yang paling menonjol di antara para murid dari Galilea, karena menurut tradisi dia adalah yang pertama menerima penglihatan tentang Tuhan yang telah bangkit) (Fiorenza, 1985). Maria juga digambarkan berdiri di antara para pengikut dan anggota keluarga Yesus yang paling setia. Maria adalah model iman yang tanpa lelah mencari pengertian iman dengan setia. Kesaksiannya yang kokoh dan berani dipertentangkan dengan para pengikut laki-laki yang meninggalkan Yesus karena takut. Keberanian, prakarsa, dan arti penting Maria ditekankan terus-menerus dan teks-teks Kitab Suci.

Maria unik karena tidak diidentifikasikan sebagai ibu, saudara, anak, istri atau kekasih seseorang. Menurut Callahan, Maria dari Magdala adalah model seorang janda yang dewasa dan enerjik, yang sukses menjalankan usaha keluarga, barangkali usaha pertenunan (Callahan, 2006). Magdala, kota tempat tinggalnya, adalah sebuah pelabuhan yang ramai di pantai danau Galilea dan tampaknya merupakan pusat perdagangan, khususnya terkenal karena hasil-hasil tenunnya. Maria dapat dibayangkan dengan sangat mudah sebagai seorang janda, sebab dengan demikian akan lebih mudah baginya untuk mengendalikan harta kekayaannya sendiri, dan ia juga akan lebih bebas untuk bepergian. Karena Maria mempunyai uang yang dapat digunakannya untuk membantu mendukung kelompok para murid (bdk. Lukas 8:3b), ia pasti telah menjalankan perusahaannya dengan menghasilkan keuntungan. Dalam Lukas 8:1-3 juga disebut Yohana istri dari Khuza bendahara Herodes (Sutanto, 1999, pp. 36-47). Ia berani melawan kutukan, amarah dan ancaman hukuman dari masyarakat dengan meninggalkan suaminya untuk mengikut Yesus. Di dalam masyarakat Yahudi yang menganut sistem patriakhal, adalah tidak mungkin bagi seorang perempuan bersuami meninggalkan suaminya untuk pergi mengikuti seseorang dan pergi mengadakan perjalanan bersamanya. Sebab seorang istri harus tunduk dan melayani suaminya (bnd. Amsal 31:10-31).

Sangat besar kemungkinannya bahwa Maria adalah seorang pemimpin sebuah jemaat kristiani perdana. Atau setidaknya di antara para perempuan, kata Elisabeth S. Fiorenza, "Mary of Magdala seems 
to have been the leader among them, since she is usually mentioned first" (Maria dari Magdala tampaknya telah menjadi pemimpin di antara mereka, karena dia biasanya disebut pertama) (Fiorenza, 1985). Kepemimpinan Maria dalam jemaat kristiani perdana juga dapat disimpulkan dari kedudukannya yang menonjol dalam teks-teks kristiani non-kanonik yang masih tersimpan, yaitu teks-teks yang beredar di akhir abad pertama. Misalnya ada yang disebut "Injil Maria" (Callahan, 2006). Ia diakui sebagai sahabat karib Yesus yang menyertai-Nya sebagai kawan dalam pelayanan-Nya. Pengalaman Maria dari Magdala ini, yaitu tentang persahabatannya yang memerdekakan dengan Tuhan, mengubah hidup dan pribadinya menjadi baru. Dewasa ini, kita dapat membayangkan Maria sebagai orang yang menyambut baik tuntunan Roh dalam jemaat yang menghormati martabat perempuan dan mendorong persamaan serta persahabatan antara laki-laki dan perempuan.

Bagi Maria Magdalena, perjumpaan dengan Yesus mengubah semuanya. Rasa sedih menjadi sukacita yang mendalam, dan keputusasaan menjadi pengharapan. Lebih dari itu semua, Yesus memanggil, memberi kepercayaan dan penugasan: "Pergilah kepada saudara-saudara-Ku dan katakanlah kepada mereka, bahwa sekarang Aku akan pergi kepada Bapa-Ku dan Bapa-mu, kepada Allah-Ku dan Allahmu" (Yohanes 20:17). Dengan penugasan langsung dari Yesus mulailah panggilan kemuridan yang sejati bagi Maria Magdalena. Kemuridan yang dijiwai oleh terang kebangkitan yang telah hidup dalam dirinya. Perjumpaan dengan Yesus yang bangkit ini kiranya dapat menjadi pola bagi perempuan di mana pun dalam keikutsertaannya dalam mengemban misi gereja. Dalam perjumpaannya dengan Yesus yang bangkit, Maria Magdalena diperkenalkan sebagai perempuan dengan nilai-nilai hidup luhur (Henrika, FSGM, 2011, pp. 233-270). Dalam perspektif pedagogis, nilai-nilai hidup tersebut adalah sebagai berikut.

Pertama, nilai pedagogis berupa kepekaan hati dan belarasa. Relasi antara Yesus dan Maria Magdalena adalah relasi yang terjalin sangat mendalam. Relasi itu memberi kepekaan hati dan belarasa bagi Maria Magdalena untuk senantiasa mengenali kehadiran dan keprihatinan Yesus di mana pun dan dalam kondisi apapun. Bagi Maria sendiri kehadiran Yesus adalah kehadiran yang memerdekakan, yang membawa siapa saja murid-Nya untuk peka hati dan berbelarasa mengusahakan pembebasan hidup ketika di situ tidak ada kemerdekaan. Maria pun menganggap perempuan sederajat dengan kaum laki-laki dalam partisipasi mereka di dalam gerakan Yesus. Maria peka dan berbelarasa pada Yesus yang mentransformasi (membarui) tradisi di masa-Nya. Tradisi Yahudi melarang tidak hanya terhadap perempuan asing yang dijumpai, bahkan terhadap istri sendiri laki-laki Yahudi dilarang berbicara di tempat-tempat umum. Laki-laki Yahudi yang sedang mendalami hukum Taurat terkena larangan keras tidak boleh berbicara dengan perempuan yang dianggap dapat membawa pengaruh jahat pada dirinya (brings evil upon himself). Bahkan sebuah literatur Rabinik yang sangat tua mengungkap sebuah doa harian yang dinaikkan oleh laki-laki Yahudi, demikian: "Blessed art thou, 0 Lord [...] who hast not made me a woman" (Syukur pada-Mu, Tuhan [...] yang tidak menciptakanku perempuan) (Irudaya, 2006). Bahkan tradisi seksis yang terpelihara di dalam gereja-gereja Reformasi tak luput dari spirit pembaruan Yesus. Yohannes Calvin, misalnya, dengan mengutip Kejadian 1:26, menjelaskan bahwa yang diciptakan sebagai gambar Allah hanyalah laki-laki, sedangkan perempuan bukan. Ia juga mengutip Kejadian 2:16 dan menafsirkannya sebagai bukti bahwa status perempuan adalah $a$ secondary degree (makhluk kedua). Akhirnya ia menarik kesimpulan bahwa status perempuan memang lebih rendah daripada laki-laki, perempuan berasal dari dan untuk laki-laki, sepanjang waktu bahkan untuk kekekalan statusnya lebih rendah daripada laki-laki (Moko, 2018; Sinulingga, 1999). Semua tradisi tersebut membenarkan kedudukan kelas dua bagi kaum perempuan, yang dibarui Yesus dengan menghadirkan relasi baru lakilaki dan perempuan di dalam sebuah masyarakat baru, yaitu masyarakat Kerajaan Allah. 
Kedua, nilai pedagogis berupa panggilan misional dan agen perubahan. Setelah sekian lama Maria mencari Yesus, dan setelah Yesus menyapanya, ia menemukan dan mengenali Yesus kembali. Maria berada dalam sukacita serta kegentaran dan keterpesonaan (tremendum et facinosum) yang mendalam. Namun, ia tidak membiarkan diri mandeg dalam kekaguman atau keterpesonaan tetapi dengan tegas ia berani keluar dari diri (dari zona nyaman), menjalankan panggilan misionalnya, masuk ke dalam dunia dan membawa manusia lain untuk juga dibawa dan berjumpa dengan Yesus. Inilah peran Maria sebagai agen perubahan dan pembawa berkat Ilahi bagi yang lain. Belajar dari Maria, Elisabeth S. Fiorenza merefleksikan bahwa:

The movement of woman as the people of God, therefore, must recover the meaning of religious initiation into the ekklesia of woman. It can provide 'godmothers" who become intimately involved with the upbringing and socialization of children and young people. It must provide a feminist ecclesial community of adults that models itself on the discipleship of equals [...]

(Karena itu, gerakan perempuan sebagai umat Allah, harus memulihkan makna inisiasi agama ke dalam gereja perempuan. Ini dapat mengayakan 'ibu baptis' yang secara intim terlibat dalam pengasuhan dan sosialisasi anak-anak dan orang muda. Ini harus menyediakan komunitas gereja perempuan orang dewasa yang mencontohkan dirinya pada pemuridan yang sederajat [...]) (Fiorenza, 1985).

Ketiga, nilai pedagogis berupa kreativitas yang bijaksana. Maria Magdalena adalah pribadi yang tidak mengenal putus asa, yang terus mencoba tetapi dalam kreativitasnya ia bertindak bijaksana. Ketika ia menyadari bahwa Yesus tidak ada di tempat di mana Ia dibaringkan dan ia menyadari kemampuan dan keterbatasannya, ia tidak diam pasif melainkan ia bertanya, mencari di mana Yesus diletakkan, dan dengan bijaksana ia memberitahu kepada para murid tentang peristiwa itu. Dan perjumpaan Maria dengan Yesus yang bangkit mengubah semuanya. Ia adalah saksi pertama, yang dalam tradisi gereja disebut "Rasul para Rasul atau "Rasul utama" (Apostola Apostolorum), demikian ia disebut sebagai "Setara Rasul" (Isapostola). Setelah menjadi saksi peristiwa kebangkitan itu, ia pun mendapat keyakinan penuh untuk menjadi pewarta yang memberkati banyak orang yang disapanya.

Gerakan emansipasi perempuan masih panjang dikerjakan. Masih kuatnya penafsiran seksis dan tidak adil gender terhadap teks-teks Alkitab menjadi pekerjaan rumah yang tidak mudah diatasi. Dampaknya antara lain, sampai kini di dalam Gereja Katolik belum diterima tahbisan perempuan sebagai imam; juga masih kuatnya budaya patriarkhal dijadikan rujukan menolak secara sadar kedudukan dan peran perempuan dalam kepemimpinan dan pengambilan keputusan dalam Gereja-gereja Protestan. Di sinilah diperlukan kacamata baru, yaitu masukan yang berasal dari hermeneutik kritis, yang tugasnya bukan lagi reproduktif (mengulang makna berupa narasi tidak adil gender), melainkan produktif (menambah makna baru yang lebih adil gender). Gereja-gereja sebagai pihak yang pertama-tama berkepentingan mengusahakan narasi emansipasi perempuan dan melanjutkan narasi Maria sebagai "rasul perempuan," sangat didorong untuk konsisten pada perjuangan yang digemakan Injil Yesus Kristus ini. Bila tidak, maka gereja hanya akan mengalami insignifikansi internal (tidak signifikan ke dalam umat sendiri karena menjadi sebab ketidakadilan gender) dan irrelevansi eksternal (tidak relevan bagi masyarakat luas karena dianggap menyembunyikan dominasi gender laki-laki atas perempuan dan anti gerakan emansipasi), antara lain karena tidak memperjuangkan keadilan bagi hak-hak perempuan.

\section{SIMPULAN}

Dasar Injili dari hidup dan pelayanan gereja terdapat dalam hubungan khas yang oleh Yesus dalam hidup-Nya dijalin dengan para murid-Nya. Ia memanggil mereka tidak hanya untuk menyongsong 
Kerajaan Allah ke dalam hidup mereka sendiri, melainkan juga untuk mengabdikan hidup mereka kepadaNya dengan meninggalkan segala sesuatu dan dari dekat meneladan cara hidup-Nya sendiri.

Bersama dengan Maria Magdalena, para perempuan dalam hidupnya dipanggil untuk terus berani mengungkapkan ide dan kreativitasnya di dalam komunitas yang namanya gereja. Di mana gereja sendiri mendandani dirinya terus untuk mengakui kedudukan dan peran perempuan. Tidak boleh lagi terjadi dalam hidup gereja, cerita seorang perempuan yang sekalipun dikenang selama Injil diwartakan, tetapi namanya tidak pernah diakui dan disebut, seperti kata Markus 14:9, "And truly I say to you, whereever the gospel is preached in the whole world, what she done will be told in memory of her" (Aku berkata kepadamu: Sesungguhnya di mana saja Injil diberitakan di seluruh dunia, apa yang dilakukannya ini akan disebut juga untuk mengingat dia) . Seharusnya, bukan karena ia perempuan maka ia dilupakan dan tidak disebut, tetapi di dalam gereja semua orang, termasuk perempuan, disebut, diakui dan diterima dengan nama dan kepribadiannya. Maria, contohnya, adalah model perempuan yang menjadikan pengalaman imannya yang menyelamatkan menjadi pengalaman iman komunitas atau bersama. Lalu, secara bersamasama kita berjalan dalam usaha mencari Allah yang hidup itu dengan menjadikan diri sebagai berkat bagi banyak orang.

Bersama Maria, para perempuan di zaman ini diajak mengemban panggilan dan pengutusan yang seluas apapun peluang dan kesempatannya. Nilai pedagogis yang Maria wariskan, yakni kepekaanbelarasa, misional-agen perubahan dan kreativitas yang bijaksana, adalah modal sosial (social capital) berharga untuk para perempuan menjalani pengutusan sebagai rasul-rasul Kristus di masa kini.

\section{DAFTAR PUSTAKA}

Ariarajah, S. W. (2005). Intercultural Hermeneutics - A Promise for the Future? Exchange, 34(2), 89-101. https://doi.org/https://doi.org/10.1163/1572543054068523

Callahan, S. (2006). Maria Magdalena dan Augustinus. Yogyakarta: Kanisius.

Chung Yen, L. (2005). Pengakuan Maria Magdalena: Saat-saat Intim Bersama Sang Guru. Yogyakarta: Kanisius.

Clifford, A. M. (2002). Teologi Feminisme. Maumere: Ledalero.

Colby, S. R., \& H. Bodily, B. (2018). Poetic Possibilities Exploring Texts With Ricoeur's Hermeneutics. International Review of Qualitative Research, 11(2), 162-177.

Fiorenza, E. S. (1985). In Memory of Her: A Feminist Theological Reconstruction of Christian Origins. New York: Crossroad.

Frederiks, M. (2005). Hermeneutics from an Inter-Religious Perspective? Exchange, 34(2), 102110.

Gadamer, H.-G. (1975). Truth and Method. New York: The Seabury.

Gschwandtner, C. M. (2017). Space and Narrative: Ricoeur and a Hermeneutic Reading of Place. In B. B. Janz (Ed.), Place, Space and Hermeneutics (pp. 169-181). https://doi.org/10.1007/978-3-319-52214-2_13

Henrika, FSGM, S. M. (2011). Perjalanan Perempuan Religius: Bersama Maria Magdalena yang Berjumpa dengan Yesus yang Bangkit (Dalam Sema; A. E. Kristiyanto., ed.). Yogyakarta: Kanisius.

Hovorun, C. (2015). Meta-Ecclesiology: Chronicles on Church Awareness. London: Palgrave Macmillan.

Irudaya, R. (2006). Significance of Jesus' Mission With the Marginalized Samaritan Woman: A Feminist Reading of John 4. Bhashyam: An Indian Biblical Quarterly Bible, 32(2), 1-42.

Johnson, E. A. (2003). Kristologi di Mata Kaum Feminis. Yogyakarta: Kanisius. 
Krueger, L. (2019). Reinterpreting Eve and Mary: A Theological Anthropology for Women. Pneuma: The Journal of the Society for Pentecostal Studies, 41(1), 91-109.

Mantzavinos, C. (2020). Hermeneutics. In E. N. Zalta (Ed.), The Stanford Encyclopedia of Philosophy (Spring $2020 \quad$ Edition). $\quad$ Retrieved from https://plato.stanford.edu/archives/spr2020/entries/hermeneutics/

Moko, C. W. (2018). Eksistensi Gender Ditinjau Dari Sudut Pandang Al-Kitab (Studi Terhadap Agama Katolik). Jurnal Intelektualita: Keislaman, Sosial Dan Sains, 7(1), 21-30.

Moyaert, M. (2017). Ricoeur and the wager of interreligious ritual participation. International Journal of Philosophy and Theology, 73(8), 173-199.

Palmer, R. E. (1980). Hermeneutics: Interpretation Theory in Schleirmacher, Dilthey, Heidegger, and Gadamer. Evanston: Northwestern University Press.

Ricci, C. (1994). Mary Magdalene and Many Others: Women Who Followed Jesus. Minneapolis: Fortress Press.

Ricoeur, P. (1980). Essays on Biblical Interpretation (L. S. Mudge, ed.). Philadelphia: Fortress Press.

Ricoeur, P. (1982). Hermeneutics and the Human Sciences: Essays on Language, Action and Interpretation. Cambridge: Cambridge University Press.

Ricoeur, P. (1995). Figuring the Sacred: Religion, Narrative and Imagination (Trans. by; M. I. Wallace, ed.). Minneapolis: Fortress Press.

Setio, R. (2006). Membaca Alkitab Menurut Pembaca: Suatu Tafsir Pragmatis. Yogyakarta: Duta Wacana University Press.

Setio, R. (2010). Mempertemukan Alkitab dan Al-Qur'an, dari Sudut Pandang Kristen. Gema Teologi, 34(1), 2-15.

Simon, J. C. (2019). Hermeneutik Paul Ricoeur dan Tugas Emansipasi: Kemiskinan, Ketidakadilan, dan Radikalisme di Indonesia. Yogyakarta \& Makassar: PT. Kanisius \& STT Intim Makassar.

Sinulingga, R. (1999). Status Perempuan dalam Perjanjian Lama. Forum Biblika 10.

Stiver, D. R. (2001). Theology after Ricoeur: New Directions in Hermeneutical Theology. Louisville: Westminster John Knox Press.

Sutanto, T. (1999). Yesus, Kaum Perempuan, dan Feminisme. Forum Biblika 10.

Tardelly, R. F. (2011). Mencari Maria Magdalena. Yogyakarta: Kanisius.

Tripp, J. M. (2019). The Divided Magdalene: the Three Magdalenes Debate (1517-1519), between Humanism and Enlightenment. In E. F. Lupieri (Ed.), Mary Magdalene from the New Testament to the New Age and Beyond. Leiden: Brill.

Warnke, G. (2020). Hermeneutics. In Oxford Research Encyclopedia (pp. 1-19).

Wilson, B. (2019). Spiritual and Material Conversions: Federico Barocci's Christ and Mary Magdalene. In W. Melion, E. C. Pastan, \& Lee Palmer Wandel (Eds.), Quid est sacramentum? (Dalam Quid, pp. 394-427). Leiden: Brill. 